Supplement of Biogeosciences, 15, 2251-2269, 2018

https://doi.org/10.5194/bg-15-2251-2018-supplement

(C) Author(s) 2018. This work is distributed under

the Creative Commons Attribution 3.0 License.

(c) (1)

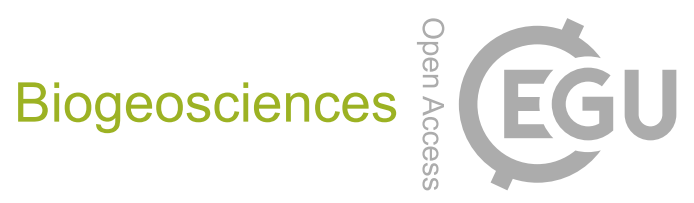

Supplement of

\title{
QUAL-NET, a high temporal-resolution eutrophication model for large hydrographic networks
}

Camille Minaudo et al.

Correspondence to: Camille Minaudo (camille.minaudo@univ-tours.fr)

The copyright of individual parts of the supplement might differ from the CC BY 3.0 License. 



S1. Lagrangian profiles from S1 to S2 of phytoplankton and SRP concentrations for four contrasted simulations to show phytoplankton and phosphorus sensitivity to flow and water temperature conditions: i) reference simulation used throughout the manuscript; ii) constant low-flow in the Loire at $\mathrm{S1}$ forced at $200 \mathrm{~m}^{3} \mathrm{~s}^{-1}$ and forced at $0.1 \mathrm{~m}^{3} \mathrm{~s}^{-1}$ in all other streams; iii) constant high-flow in the Loire at $S 1$ forced at $1000 \mathrm{~m}^{3} \mathrm{~s}^{-1}$ and forced at $0.1 \mathrm{~m}^{3} \mathrm{~s}^{-1}$ in all other streams; iv) constant water temperature simulation, $\mathrm{T}=13.7^{\circ} \mathrm{C}$ in all streams at all time. Phytoplankton development was much more affected by shorter travel times than by colder water temperature. P availability played a major role, and SRP exhaustion was reached 2.5 days after the starting date from $\mathrm{S} 1$ for all simulations except for the high-flow simulation where no P limitation was simulated because travel time from S1 to S2 was not long enough. 